\title{
Labyrinthe
}

$11 \mid 2002$

Numéro 11

\section{Portraits du bourreau}

\section{Emmanuel Taïeb}

\section{(2) OpenEdition}

\section{Journals}

Electronic version

URL: http://journals.openedition.org/labyrinthe/657

DOI: $10.4000 /$ labyrinthe.657

ISSN: 1950-6031

\section{Publisher}

Hermann

Printed version

Date of publication: 14 January 2002

Number of pages: 51-66

\section{Electronic reference}

Emmanuel Taïeb, «Portraits du bourreau », Labyrinthe [Online], 11 | 2002, Online since 15 April 2005, connection on 07 May 2019. URL : http://journals.openedition.org/labyrinthe/657 ; DOI : 10.4000/ labyrinthe. 657

This text was automatically generated on 7 May 2019.

Propriété intellectuelle 
Portraits du bourreau

Emmanuel Taïeb 